Theatre Research in Canada

Recherches théâtrales au Canada

\title{
Barry Freeman Staging Strangers: Theatre and Global Ethics. Montreal \& Kingston: McGill-Queen's University Press, 2017. 198 pp.
}

\section{Eury Colin Chang}

Volume 39, Number 2, 2018

URI: https://id.erudit.org/iderudit/1058052ar

DOI: https://doi.org/10.7202/1058052ar

See table of contents

Publisher(s)

Graduate Centre for the Study of Drama, University of Toronto

ISSN

1196-1198 (print)

1913-9101 (digital)

Explore this journal

Cite this review

Chang, E. (2018). Review of [Barry Freeman Staging Strangers: Theatre and Global Ethics. Montreal \& Kingston: McGill-Queen's University Press, 2017. 198 pp.] Theatre Research in Canada / Recherches théâtrales au Canada, 39(2).

https://doi.org/10.7202/1058052ar

All Rights Reserved (C) Theatre Research in Canada / Recherches théâtrales au Canada, 2019
This document is protected by copyright law. Use of the services of Érudit (including reproduction) is subject to its terms and conditions, which can be viewed online.

https://apropos.erudit.org/en/users/policy-on-use/ 


\section{Notes}

I Die Schutzbefoblenen (translation, The Suppliants). Directed and designed by Nicholas Stemann, and performed at the Transformatorhuis Westergasfabriek, Amsterdam.

\section{Works Cited}

Burian, Jarka. The Scenography of fosef Svoboda. Middletown, CT: Wesleyan University Press, I97I. Print.

Doona, Liam. "Hope, Hopelessness/Presence, Absence: Scenographic Innovation and the Poetic Spaces of Jo Mielziner, Tennessee Williams and Arthur Miller." Exploring Scenography. Ed. Malcolm Griffiths. London: The Society of British Theatre Designers in association with Nottingham Trent University, 2003. 55-64. Print.

Holmberg, Arthur. The Theatre of Robert Wilson. Cambridge: Cambridge University Press, 1996. Print.

Howard, Pamela. What is Scenography?. Abingdon and Oxon: Routledge, 2004. Print.

McKinney, Joslin and Scott Palmer, eds. Scenography Expanded: An Introduction to Contemporary Performance Design. London: Bloomsbury/Methuen Drama, 20I7. Print.

Parker, Ellie. "Talking About Theatre Design." Studies in Theatre Production, I3.I (1996): 72-82. Print.

Rewa, Natalie. Scenography in Canada: Selected Designers. Toronto: University of Toronto Press, 2004. Print.

\section{BARRY FREEMAN}

\section{Staging Strangers: Theatre and Global Ethics.}

Montreal \& Kingston: McGill-Queen's University Press, 2017. 198 pp.

\section{EURY COLIN CHANG}

In an age often characterized by terms such as mass migration and globalization, Barry Freeman's book has deep resonance and application within theatre studies and other socio-political fields. His book astutely explores how the current climate fosters a simultaneous fascination with, but also hesitation towards, accepting "strangers."

Chapter One situates the study within Toronto's theatre milieu, then as expected, credits the many scholars who laid the foundation for Freeman's research: including but not limited to Charles Taylor ("The Politics of Recognition"), Neil Bissoondath (Selling Illusions) and Sunera Thobani (Exalted Subjects). Overall, Freeman makes strides at further developing an "ethical way of looking" by generously quoting the work of Sara Ahmed, and by engaging with her concerns regarding the production of strangers through an encounter which "itself already assumes the possibility and virtue of 'knowing' strangers" (59). This book provides 
a loose (not overly prescriptive) taxonomy of aesthetic forms and narratives, drawing focus to the ways in which strangers are seen, and possibly interpreted, within Canadian theatre. Chapter Two is entitled "Church Basement Globalization," a term the author uses to describe the multicultural theatre of the I970s and '8os. Here, Freeman examines Nové divadlo, a Czech-Canadian theatre company helmed by Adolf Toman, who also ran the Limelight Dinner Theatre. This particular case study lays a historic foundation and context for the following case studies.

Chapter Three is entitled "Domesticating the Stranger." This section unpacks plays with inter- or multi-generational elements such as Betty Quan's Mother Tongue, which revolves around "the children's loss of knowledge about their ancestry and language, and most of all, the forgetting of the family's story of flight and passage" (63). By extension, the author examines Catherine Hernandez's Singkil, which traces a mother-daughter connection before moving towards a well-known play-turned-television series: Ins Choi's Kim's Convenience. The latter is positioned within Soulpepper's primarily "Euro-American repertoire" and the CBC, which has since committed to producing multiple seasons of the highly lauded comedy. Freeman ponders: "My critique is thus not directed at Choi's play-which is ably crafted and has been warmly accepted by audiences for good reasons - so much as toward the situation of the encounter in which it is implicated" (80). The author's framing of Kim's Convenience, under a sub-heading "Domestication as 'Making Safe,"' is appropriate given his question whether or not Choi's play "invites its audience into a post-racial fantasy wherein racism is a thing of the past" (79). There is a deeper layer to this interpretation. Take for example the script's nuanced, cross-racial explorations-especially in scene eighteen, when Appa, the father, subversively challenges one-sided media portrayals and polarization of Afro- and Korean Americans after the L.A. Riots (1992) - and it becomes clear that Choi uses a nuanced and humorous social commentary to address, and disarm, complex and thorny "racial" issues. I align with Freeman's general observation: Choi's play stands in contrast to many of the other case studies, where the "stranger" is portrayed as a threat or point of struggle within Western culture.

Chapter Four is entitled “A New Melodrama of Globalization.” The author examines representations found in Rahul Varma's Bhopal and Ahmed Ghazali's The Sheep and the Whale, productions that shift focus away from the localized, Canadian immigrant narratives to a more globalized focus whereby strangers are distant and excluded from modernity (85). These representations lead readers into the territory of social justice, human rights, and issues of global inequality. Freeman then reminds his readers that melodrama provides audiences with satisfaction through "its expression of clear moral order in a world otherwise lacking transcendent certainty" (87). This definition, stemming from the nineteenth century, is then placed in a more contemporary context whereby "the high levels of social and economic inequality of twenty-first-century neoliberal capitalism have again fertilized that soil" (8889). Overall, this chapter reveals the limitations of pity, and how some audiences come to see "strangers" or others not like themselves, but as problems or issues. When describing The Sheep and the Whale, Freeman draws attention to the ship's captain, who is more inconvenienced than horrified by the disaster and plight of refugees. In fact, he is troubled by the fact that he must convince port authorities in Europe and Africa to accept deceased bodies without paying taxes (9r). 
In the final chapter, Freeman muses how audiences grew to be a focus of the book, but admits to the fact that many interpretations were limited to his own subjectivity and speculation of how others might experience such encounters (I4O). Ironically, the few times Freeman allows himself self-reflexive space is when the book becomes (at least for me) potentially transformative. For example, in the book's Prologue, the author describes an experience as a witness-participant in The Stranger, a site-specific work by DopoLavoro Teatrale. After being prompted to wear a mask while looking at himself in a mirror, he writes: "I was disappointed by its suggestion that the stranger was in fact me...[which]...seemed to forfeit the possibility of really 'knowing' strangers" (xx). In another encounter at the end of Jovanni Sy's play, Taste of Empire, Freeman is offered a taste of rellenong bangus, a stuffed Filipino milkfish. He writes: "the performance had presented the dish as a product of both colonial history and the exploitative labour of strangers, in which, by tasting, the audience would be implicated. Like most other spectators who had attended the performance that night, I chose to eat" (II2). In both examples, the author boldly implicates himself in the action. Indeed, it would have been fascinating if Freeman had added more of such interrogations to the book, reconciling further over his personal disappointment during The Stranger or his ethically imperfect consumption of fish during Taste of Empire.

Also, in chapter five, the author draws attention to Debajehmujig Storytellers, illuminating one show of particular importance: "Their Global Savages project was created in part to make their style of performance storytelling responsive to the places to which they travel. It was also a response to the way [I]ndigenous peoples have been made strange within mainstream Canadian culture" (I24). Members of this company employ a dialogic process that is partly scripted, partly improvisational yet interactive. Commenting on how the company performs in the street, literally engaging with new contexts each time, Freeman adds: "I grew to understand that they construct their projects as they do on account of the critical importance of building relationships in all their encounters with audiences and fellow artists[...] thus designed to offer representation as a site of symbolic intercultural dialogue" (I26).

The question remains whether the experience of seeing strangers, of eating their food and hearing their stories onstage encourages empathy or ethical engagement with "strangers" in daily life. The narratives in Staging Strangers: Theatre and Global Ethics transcend the local and transnational, intercultural and Indigenous, casting a wide net over multiple cultural sites and time periods. Well-researched and thorough, Freeman's scholarship into "strangers" and Canadian theatre is worthy of deep consideration. 